\title{
The Weave of My Life: a Dissection of Dalit Existential Struggle and the Resistance through the Marxist Lens
}

\author{
Samim Bulbul Ahmed \\ Abhirampur Junior High School, Chetua, India \\ sbahmed@gmail.com
}

\begin{abstract}
Another name of life is existential struggle; so long man struggles either against adverse conditions or against their own selves for livelihood and common amenities to live on, so long they will survive. Continuous struggles — class struggle or struggle against nature or against social, religious, economic institutions-- bring radical changes in human life and usher in a revolutionary way of sustaining life. Dalit, working-people's life is full of struggle and their ghetto is nasty, unhygienic, and under pressure of bourgeoisie and brahmanic dominance. In short, they are circumcised in respect of economic, social and religious perspectives and their hard-some struggle against all these, provide sustenance and life force to sustain their life in impervious backdrop. Marxism analyses the relationship of oppressed and oppressor from materialistic approach and tries to find out the real cause of suffering of the oppressed, proletariat people. Taking Marxism as tool of analysis, this research article tries to probe into deep the cause suffering of Dalit people and their struggle against oppressive institutions and mechanisms. At the same time, it delves into the very incipient point of being stigmatized as dalit, untouchable, low born, proletariat and speculates over the way of emancipation.
\end{abstract}

Keywords: Marxism; class-struggle*; proletariat; bourgeois; dialectical materialism; hegemony; patriarchy

*class and caste are used interchangeably in this paper.

\section{Introduction}

Dalit literature is precisely that literature which artistically portrays the sorrows, tribulations, slavery, degradation, ridicule and poverty, endured by dalit. This literature is but a lofty image of grief (Deivasigamani, 2019; Limbale, 2004). Urmila Pawar's "The Weave of My Life", being a memoir, presents the life struggle of the Mahar community in stark and down to earth expressions and with the each march of line, the readers come to know about their struggle for existence in the rocky backdrop of Sahyadris. The Weave of My Life begins with a detailed description of the harsh landscape of the Konkan region on the West coast of India and the relation this Dalit woman - their own life's harsh and full of toil- have with this landscape.

The range of the Sahyadris runs along the coastline and there is a sheer drop in the sea. The main crop is rice; the poor grow a form of red Millet that thrives on the thin soil.
(Pawar, 2009, p.13)

The marginalized, working class women need to go the market of Ratnagiri to sell bags, bamboo wares, crabs ,mule fishes etc, by walking and crossing mountains and rivers. In spite of being earning members of their family, they face hegemonic dominance not from the upper class but from their own clan too. In every respect of life-in social, religious and even in economic life-they are oppressed and castigated. Their tolerance breaks the limits and gradually the Dalit proletariat people unite together to resist the dominance -the very view of the Marxism that dominant and the oppressed people cannot go for ever peacefully, due to the conflicting nature. As per Marxism, everything has its contradiction or negation and so long opposites exists, contradictions exist till the contradiction ends with a better "synthesis" and fully realized expression. The oppressed, down trodden, low caste/class 
people need to unite and snatch their own right from the privileged, aristocratic upper class people.

\section{Method}

The researcher has adopted observation and deep and exploratory study with analytical, descriptive, and comparative methodology for this paper; reliance has been placed on books, journals and source database etc.

\subsection{Main Text}

Marxist scholars interpret the problem of dalits within the Marxist class theory of exploitation and economic inequalities (Thorat \& Madheswaran, 2018). The prime reason behind all Dalit discrimination-be it legal, social, political, or religious-lies in the economic structure of the society on which the superstructures, such as social institutions, media, cultural ideologies, are erected (Guru, 2020). In fact, all the institutions work for the upper class, aristocratic people and always try to imbibe among the dalit working class people some ideas, ideologies in such a way that they unknowingly follow them with servitude. Urmila through his memoir tries to unweave the hegemonic, cultural, ideological and economic dominance, thereby striking the very concept that influential most often frames rules and regulations for their own benefits and create mindsets among the people in such a way that they follow them and obey them with genuflecting servility. The upper caste/class people imposing some restrictions deprive them from education and exploit them by using them as wage laborer.

Since time immemorial, our society had been divided into four sections and this idea is propped up by our religious scriptures too. Bhagvad Gita established the belief in the four castes by insisting, these were created by Lord Krishna himself. It advices members of each caste to follow the duties prescribed by script faithfully and says that by doing this, they would be on the path to Salvation. According to Rig Veda, the oldest of the four Vedas, the distinction of the four Varnas dates back to the origin of the human race. That is to say at the time of creation, Brahmin was born from the mouth of purus (the primeval man), the Kshatriya from the arms, the Vaishya from his thighs and the Sudras from his feet. However, the four Varnas were actually established during the middle of the later Vedic era (1000 to $600 \mathrm{BC}$ ) which marked the formation of Aryan agrarian society. It was during this time that the above Myth was created and inserted into the Rig Veda, the most important scripture of brahmanism in order, which legitimises the four Varnas system again. According to those who are pleasant conduct here, the prospect is, indeed, that they will enter a pleasant womb, either the womb of a Brahmin or the womb of a Kshatriya or the womb of a Vaishya. But those who are of stinking conduct here, the prospect, is indeed, that they will enter a stinking womb either the womb of a dog or the womb of a swine or the womb of a Chandala (Massey, 1997).

In fact, this is the incipient point of social disparity and discrimination. On the scale of hierarchy, the dalits, untouchables, being at the very nadir point, feels inferiority complex among them and the upper class people exploit them by depriving them from entering into educational institute, using common well for drinking water and even in taking part in religious festivals (Kotani, 1997). Marxism does not pay attention towards religion but in human race it plays crucial role; religion works as opium and determines the fate of the depressed people. This showed that the Varna system had the backing of the ruling Savarnas caste or aristocrats who used the system and 'superstructure' and its legitimating texts to increase their exploitative hold over the lower castes.

Urmila Pawar has taken up ample care to highlight the religious disparity in her memoirs; the Mahar could not touch any 
sacred scriptures neither perform religious gesticulations. The upper caste/class brahmins always exploited them. During the Holi celebration, Mahar people preformed all the laborious task such as cutting trees and carrying them to Chandaki Debi's temple but at the auspicious moment, they were deprived of touching holy palanquin.

Mahar youths are made to do the hard work of cutting down branches and trunks of trees and carrying them to the field where a fire would be lighted at dusk. But they are not allowed a place in the celebration; it is the upper caste/class men who carry the palanquin of the goddess, and the Mahars are forbidden to touch it.

(Pawar, 2009, p.15-16)

Contrarily, the upper caste/class people railed them. Even for any religious need, if brahmins are called for, they always maintained safe distance; even some solemnized marriage ceremony from a tree but they never forget to collect his fees.

$\mathrm{He}$ (Brahmin) would climb a tree on the outskirts of the neighborhood, muttering some chants.....So bhatj I (Brahmin) would climb the tree because he did not want to be polluted with the shadows of caste bythe people of our Mahar neighborhood [...] Then the priest would climb down, sprinkle holy water from his panchapatra."

(Pawar, 2009, p.27)

Urmila strikes at the very core of sham hypocrisy of Brahmins and asserted that they always looked at the Mahar people as untouchable and worthless fellows. Even once Urmila went to buy mango pickle to a brahmin's house and she was made to wait for a long time outside of his gate.

Taking care not to touch or even let my shadow fall on things lying around, I would reach the cement steps of their house [...] From there I tried to peep into the house, trying to see if anyone was around .But it would look quite deserted from where I stood. Then I had to shout, "Hello, anybody there? I want some pickle, worth two paise".
After I had shouted three of four times, someone would peep out and ask.

(Pawar, 2009, p.61)

According to E V Ramaswami Naicker Hinduism was not a religion but system created through conspiracy of Brahmanism (Pumpirikunnu, 2007, p.30). Even brahmin raped dalit, Mahar women and yet went on without getting any kind of punishment. Ambedkar, in his 1957 book "The Buddha and His Dhamma", stressed religion can never differentiate, it is the practitioners of religion who for their own benefit draws line of segregation and stratifies people. He burned Manusmriti and got converted into Buddhism. Following his foot print, many Mahar people converted themselves into Buddhism. In fact, they discarded the religion of dominant class with the view:

\section{[...] ye Gods, you were never good to us.}

(Pawar, 2009, p.183)

Marxism is grounded on the reality not on idealism and interprets life in terms of matter, wealth, and class struggle between the dominant and dominated section. It believes that all the discriminations are due of wealth and power. The Dalits, untouchable, proletariats are dominated by the brahmanic upper caste people because the dalits have no money, hence no power; on the other hand, 'money speaks' seems to be quite appropriate for the dominating class. They have in their hand judicial system, religion, and societal norms by which they safeguard themselves from any kind of tension, arising due to the tussle between the dalits and upper caste Brahmins and, monopolize everything. In fact, the 'base' such as the means of production, machinery etc supports the 'superpower' such as religion, culture, education etc by which the upper class people control the lower class people. True to this point, Urmila points out that there were no access to education of Mahar people; they could not enjoy food along with the upper caste people in marriage 
ceremony and even were forbidden to draw water from river but from only a particular place.

The dalits were supposed to collect drinking water from a particular part of the river. One day, early in the morning, people from Maratha community deliberately took their buffaloes and bullocks to the designated part of the river to wash them.

(Pawar, 2009, p.65).

Even in those educational institutions where Dalit people got enrolled but there teacher inspected their slate from a distance.

\begin{abstract}
Some Mahar children also went to school, but they had to sit outside in the courtyard. The teachers taught them and examined their slates from a distance. They would hit the children with stones if they made any mistakes
\end{abstract}

(Pawar, 2009, p.29)

Why are Dalit's ghettos nasty and unhygienic and far away from the town or villages of upper caste people? Is there any monopoly that the dominant classes use to keep them away? Marxism tries to investigate or interpret it from socio economic perspective. In Ratnagiri the villages like Phanswale, Patravane are far from the dominant class, people, or habitation. In the theory of class struggle in Marxism, it is the duty of the upper caste/class people to dominate the lower caste/class by means of cultural hegemony. Since birth, Dalit people learn that they are inferior and should shun touch of the upper caste /class people; lest they pollute the village of brahmins they use another path through which the Brahmins never tread on. Our religious scripture "Manusmriti" vouchsafes it. Manu writes,

The dwelling of Chandala and sapaka(low caste, lower class equivalent) should be outside the village.

(Manu 10:3 in Massey, 1997)
So that is why, they live in far off places from Ratnagiri, which the Mahar women describe as "God forsaken" and is precarious enough in every respect, where one wrong step would straight away lead to death. The more the Mahar women toil to reach to the market of Ratnagiri, they upbraid their mool purush.

The vexed women would utter the choicest abuses, cursing the mool purush of our family, who, had he heard them, would have died again.

(Pawar, 2009, p.21)

While Urmila Pawar points out the hardship of the Mahar people, Marxist critic tends to bestow the view that to exploit the lower caste people and deprived them from the common civic amenities of human life, dominant section of society deliberately use religion and ideologies to influence them on. The Brahmin takes the position of priest and teacher, the Kshatriya takes charge of politics and military, and Vaishya forms the group of collector and merchants and all collectively determine ideologies to influence on lower class. Manu writes,

They (lower caste) should be depriving of dishes and their property consists of dogs and asses. Their clothes should be garments of the dead and their ornaments should be broken dishes and they must constantly wonder about.

(Manu 10:3 in Massey, 1997)

So far, the description is quite matching but even for slum area, dalit lower caste, proletariat, it is no less unsuitable. In Mumbai where Urmila jobs in a government sector she visits several slum areas of Kurla for the sake of women's organization and she has real experience.

One day I was invited to speak in a slum in Kurla. There was no road that one could walk on to get access. The activists had created a makeshift path by spreading tiles on the open drains between rows of tightly packed huts. We walked carefully, trying hard to keep our balance, till we reached a small open space in the middle of the slum. Many children and 
men were sitting on jute bags spread on the ground. A table and a few chairs were assembled and a banner was put up at the back. When we got there, an activist hurriedly asked me to sit down on a chair at the far end. When I glanced at the chair at the other end, I saw a big garbage can absolutely overflowing near it. I breathed a sigh of relief. So I was sitting in a comparatively better place! I did not have to suffer the stench! But after some time, the typical stink of public toilets assaulted my nostrils. When I looked over my shoulder, I saw five or six men standing with mugs of water in their hands behind the banner.

(Pawar, 2009, p.164)

The Dalit people who have come from their villages and work here as scavenger faces terrible discrimination and caste oppression. Due to their socio-economic back ground, they are compelled to live in slam, as no one is willing to rent them rooms. Even Urmila herself faces social discrimination when she goes to rent a room.

After her marriage, Pawar is subjected to discrimination when she and her husband look for rented accommodations in the town of Ratnagiri; they have to vacate two rooms after the landlady discovers their caste.

(Pawar, 2009, p.15)

In Mumbai, the rich higher class people live in high rise; on the other hand the Dalit people live in a slum area; the class discrimination and the dichotomy of economy and social inequality that lie between upper class and lower class people are markedly discernible and visible.

Marxist theory evinces in us a sense that always upper class people try to engage the lower class people in menial jobs or use them as a 'means of production' but will not give proportionate value of their labor. Marx believes that forces of production enable people to enter into social relationships by participating in economic life (Marx, 1873). Rich exploits the poor; more over they frighten them in the name of economic, social and religious institutions. When Urmila's son dies in accident, after few days, a colleague comes and advices her to read scriptures to avoid god's punishment.

Let me tell you something" she said. Now don't be angry with me. God's justice is slow but certain! One never knows when he will decide to punish! You still have two girls to look after. You have a husband. Listen to me. Read Dattagurucharitra regularly.

(Pawar, 2009, p.190)

Actually, it is this oppressive ideology which frightens lower class/caste people to subjugate. Unless all proletariat unite and protest for their rights, the oppression will go on and on. In The Weave of My Life, the Mahar people weave bamboo wares, collects firewood, grass from the forest of Sahyadris, and go to sell them in the market.

Women were compelled to make the journey to the market because they had to sell their wares in order to survive; bundles of fire wood or rice bags or grass or whatever merchandise, covered with leaves or woollen blankets.

(Pawar, 2009, p.21)

The arduous and hard some toil in carrying loads, ignite their irk; when they hear the bid of buyers, they become disappointed and depressed. The following excerpt will divulge out the real picture of class dominance, and economic exploitations. A Mahar woman said,

See, I took my bunch of sticks on the stand. Two guys came asking me about the price. Then they started chatting about something else. So I said you are buying this? Are not you? This bunch is quite heavy on my head. So they said, all right, put it down. So I did. Then they tried to lift it and feel its weight. Then one says, Ha this is so light, how can you say it's heavy? I told him straight to his face, it's heavy for us because we come crossing two-three hills with that on our heads! We're bound to find it heavy!

(Pawar, 2009, p.26) 
All the people served upper caste/class and worked in their field as a means of production.

\begin{abstract}
All of them had served the upper castes in different ways throughout the year. Someone had labored in the fields, woven baskets of various shapes and sizes for them. They would ask to be compensated for their work. Especially houses that performed the customary Mahar duties, such as beating the dhol, disposing of dead animals, delivering messages would go to beg as a matter of right.
\end{abstract}

(Pawar, 2009, p.47)

But they were given meagre salary. According to Marx in a capitalist society the work done or invested by the labour power usually exceeds wages received in return. It is this unfairness that characterizes exploitation of the proletariat (Mahar) by that bourgeoisie (upper caste). Marx says Accumulation of wealth at one pole is at the same time accumulation of misery, agony of toil, slavery, ignorance, brutality, mental degradation, at the opposite pole (Marx, 1873).

In his view, ultimately, the proletariat would wake up in this unfairness and try to have a share of the surplus value which would cause conflict between the two classes and struggle for the working class. Now gradually rebuttal comes not on physical level rather in the form of organization, clamoring for their rights. Ambedkar (1957)organized campaign against Dalit oppression and casteism. Even the dalit-working class- woman are coming ahead with their own agenda, along with the discrimination on the basis of social religious and economy. Babytai Kamble, Chhaya Data etc are struggling for their rights though people speak against them.

And people also told us, "You are Hypocrites! However, we paid no attention to such remarks and continued with our work. Finally our organization Samwadini was opened.

(Pawar, 2009, p.176)
Certainly, due to their raising voices, lower class people unite together and pave the path of revolutionary' thesis-anti thesissynthesis' circle as per the rules of dialectical materialism for better future. Mahar people are dependent on upper caste/class dominating people. Urmila's father was dependent on the Lanjekar to sell mangos.

Lanjekar was a big time mango merchant who bought mango trees on contract immediately after they flowered.

(Pawar, 2009, p.29)

The Lanjekar bought mangoes from Urmila's father and they again sold them in the market or exported to other foreign countries.

Hapoos mangoes from Ratnagiri reached the Arab countries but never came to us.All that came our way was the ordinary mango called raiwal.

(Pawar, 2009, p.71)

Here again, class oppression and exploitation is evident. The proletariat, i.e., the Mahar dalit people, is bound to sale their product at low prices. So long collective consciousness will not grow among the Mahar people, they will go on languishing such exploitative mechanism. Even unknowingly, they subjugate their own ambition to the upper caste people and become puppet to their hands. Just for the sake of some money, they lease their own mango trees and buy some rotten mangoes. As per Marx's ideas, the struggle between the dominant section of society and the dominated section of society will always go on and on and the subsequent "win and defeat" will determine the future of both section.

Domestic life of Mahar women and their relationship with men or patriarchy also comes into the acumen of Marxist critics. Marxism stresses that society consist of two type of people-upper class or bourgeois and the lower class or proletariat and does not pay much attention to gender, 
religious beliefs, etc. Though the dalits are constantly in struggle against the upper class people; again in micro level, they are also engaged in struggle among themselves. Patriarchy exploits the feminine entities and brings them fore into the precarious struggle for existence.

Every house has drunkard and daughters in laws were always despised and bashed up.

(Pawar, 2009, p.2)

Every house had its own share of drunkards. There would be at least one woman among them badly bashed up by her husband. She would walk painfully, somehow managing to drag her aching body along the way.

(Pawar, 2009, p.23)

In short, women are doubly oppressed; first as dalit working class to the upper class and then as women to patriarchy. Therefore feminist Marxism as new genre of criticism has appeared. Manjulatai faces domestic violence in her husband's house due to the socio economic situation. Manjulatai has to work hard- not to work hard butto slavefrom morning to till night yet at night women like her are left to eat left-over food as if the master of the house, showing some leniency on her, offers her some food. Even Urmila protests against the patriarchal dominance, coming from Harishchandra. Harishchandra creates hurdle on her getting Masters of Arts degree. Urmila passively over tunes it. Again, when he asks for conceive a baby, she says,

how simple and easy it was to have a baby like saying let's have one more cup of tea.

(Pawar, 2009, p.144)

It seems that just like a slave, Urmila is bound to obey every order. In fact, the master- slave relation boarders on the existential struggle between the dominant and dominated section of society.

Marxism believes that there are three types of struggle; the first one is economic struggle where workers try to have some economic concessions such as high wages, less working hour. The second struggle is political struggle which includes election, local councils or any form of protestations. The third struggle - the ideological struggle - is the most important; according to Marx it is about freeing workers mind from bourgeois ideas and prejudices. The Mahar community faces all kinds of struggle to sustain their life. With the passage of time, some upper caste/class customs become part and parcel of their own culture. Manjulatai took her English coaching from a brahmin upper caste teachers and therefore she imitated them in her conversation. Urmila herself went through ideological dominance. Initially Urmila referred her mother as 'Aaye' but later when she began to stay in Mumbai and came into proximity of the upper Marathi people and since then she mentions her mother as 'Aai'. Mahar people Sanskritised few dalit terms such as 'namkaran' instead of 'barse', a dalit term for naming ceremony. Even several religious festivals of the brahmins integrated into the Dalit culture. Diwali are now being celebrated by Mahar people; upper class people induce their own ideologies among the dominated class and unconsciously make them their slaves. Whatever the dominated section do under subservience of such ideologies, surely the dominating class will be benefited. Marxist theorist Louis Althusser's theory of interpellation on how 'we are always ready subject' (illustrating with the help of policeman who says 'hey' and people on the spot answers to his call as if policeman is talking to them, though it is not intended to) actively puts cursors on the dalit or dominated people and avers out that subaltern, lower class people are always ready to accept ideologies of upper class.

The Mahar people after staying in Mumbai and working there as scavenger when come to their own village they carry with them the upper class affectations. So long the ideological state apparatus be affective on Mahar people, so long they will live on the subsist of upper class people. In fact, such type of ideologies, serving the upper class people are so much alluring, 
though passively exploitative, that Mahar people can't shun in anyway.

Even the dalit educated service holders often tend to wear the garb of upper caste/class people and behave just like the 'haves'. Whenever Urmila along with colleagues goes to houses for membership collection for organization in Mumbai she meets several dalit couples who are living under the disguise of upper caste people. In fact, they fear to disclose their own true identity. These Mahar people behave in such a way that no one can find out their true identity. This shows how much subservient the oppressed class is to the ideologies of upper class people; there is even no sign, disclosing their true identity such as picture of Ambedkar (1957). Even they themselves were indifferent towards their struggle against oppression and exploitation. Even some people bashed them out of their houses. After getting some money and becoming spurious in nature those people assume ideologies of bourgeois or upper class people. Marxist critics believe that due to the incessant class struggle the oppressed people get some benefit to improve their socio economic condition but later they forget everything and subjugate before the upper class people. Though the Marxism brought about Balsevik revolution in 1917 in Russia but it is not always true that struggle must result in revolution. It is the human nature that when extremity comes in regard of endurance people burst out, clamouring for their demands but whenever upper class people throw some water of benefit on them, the oppressed people gave in before them .Here in the present memoir, we experience the same situational illustrations when Dalit or marginalized people speak out of their rights and freedom but at the end of the day, they finally revert towards the upper class people and accepts them and their culture cordially.

But fortunately, the conditions of Mahar people is gradually improving .Even in Mumbai due to the continuous seminars on women liberation, women emancipation, dalit improvement, consciousness and resistances are developing among the Dalit people. They are now uniting and protesting against all kind of exploitation and oppression. Government pays heed on their demands and takes measures to alleviate their problems by reserving for them, by giving them access to education, by employing them in service sector etc. Even in villages of Ratnagiri, when Urmila returns home after sojourn of so many years she sees the tarred roads, tiled houses, electricity poles etc.

\begin{abstract}
The rough hewn paths, full of stones and pebbles, were transformed in to tarred roads and looked like sleek black cobras, disappearing fast through the trees. Trees adorned both sides of road, their huge trunks painted red and white and numbered. Then there were electricity poles, bus stops, clusters of tiny, well-built houses peeping through the trees. Development from the cities had indeed flowed into the villages.
\end{abstract}

(Pawar, 2009, p.181)

And beautification of their village is also evident there. The burial ground of the Mahar community has been beautified by establishing Buddhist monk. Dialectical materialism views that two opposite forces are in constant struggle- upper class tries to get much more wealth and the lower class tries to improve their economic condition and the consequent result is revolution. A clash of tension appears between them, resulting in some future- benefit. Upper class people show some leniency and give some facilities to the lower class people, thereby, improving their condition .As a result of the dialectical materialism, the condition has improved for them. In the "Communist Manifesto" Marx wrote that the history of hitherto existing society is the history of class struggle (Marx, 1873). This means that class struggle pushed society from one stage to the next in a dialectical process. In each stage, classes struggle because one group felt inferior to the other. For instance, in feudal stage, feudal lords 
owned the land used to produce agricultural goods, while serfs provided the labour to plant and harvest crops .The overthrowing of the feudal Lords give rise to capitalism.

\section{Results and Discussion}

The condition of Mahar people is really breath-taking, as alongside of nature, they face terrible social and economic torture. Upper caste/class people exploit them, coax them in menial activities in low wages but again stigmatize them as 'low born' or 'untouchable'. They feed on rotten fish, leftover foods and dregs of rice.

It comes to us that 'mean of production' such as work force, machinery, money etc shapes 'superstructure' such as religion, education, media ,etc. and again, 'superstructure' determine 'base'. Mahar people are constantly facing exploitation from socio-political-religious perspectives. Due to the revolution, religion can't be radically changed in anyway. Actually religious stigma has been considered as congenital stigma which can't be eliminated by some rites or deeds. Due to the inspiring writings by the dalit writers, dalit consciousness has grown and exploitation discrimination and casteism holds are seemingly to be changing in quality and quantity. Somehow due to the reservation, the working class dalit people improved their status as a result of the constant struggle but they again fall behind after few days. Again another revolution needs. So in the process of circular motion 'thesisantithesis-synthesis' they find themselves in the same exploitative grounds. Urmila while campaigning for women liberation, women liberation and equality, she sees that few Mahar people change their economic status but other factors such as caste, politics, stigma etc again try to exploit them. In fact, changes come but nothing seems to be changed for this working class people.

Dalit consciousness, arising out from the pain and rejection, opens up a new vista for dalit Marxism. It is a Marxism that tries to explore dalit's life and their sufferings from dalit point of view. This type of Marxism not only analyzes dalit people from socio economic-conditions rather they throw dissecting lightof analysis on all around the life struggle of the dalits. Thus it is fully dalit, as well as fully marxist. So dalit people- struggle and aesthetics should be judged from dalitist- approach. The concept of Marxist literature originated from a theoretical understanding of society but the concept of dalit literature originated directly from lived experiences.

Marxism puts emphasis on humanity and equal distribution and abolition of private property. If it is applied for dalit, someone needs to monitor it and after few days that 'someone' will start to exploit them. Being fearful one may subjugate to god and truthfulness but being free and desperate, one must oil his own wheel, thereby, opening up new prospects of exploitation. The diverse attitude of several dalit communities such as Tondekar, Kashelkar, Naneejkar and Mahar can't be bought together into unity.

\section{Conclusion}

Urmila, though threw virulent attack on the patriarchy and caste oppression in her memoir but we must have to remember that patriarchy and caste oppressions are another name of class exploitation and deprivation. The labour based division of caste in India inevitably brought racial prejudice. Moreover, with the change of sociopolitical scenario, there appeared many classes in our society. The mean of production is gradually changing from physical labour to machinery.

Thus, to a certain extent, Marxism is not always acceptable. Marxism is no longer applicable in the same way it would have been 50 years ago due to mass production, mass consumption and development of technology, militarization and totalitarianism. Marxism is not able to totally address dalit issues, but the inducement of the theory of class struggle and ideological dominance, in fact, help to 
build dalit consciousness and resistance among Mahar people.

\section{References}

Ambedkar, B. R. (1957). The Buddha and His Dhamma. Siddhartha College Publications.

Deivasigamani, T. (2019). Subaltern Discourses. MJP Publisher.

Guru, G. (2020). Neo-Buddhism, Marxism and the caste question in India. Classical Buddhism, NeoBuddhism and the Question of Caste.

Kotani, H. (1997). Caste system, Untouchability and the Depressed. Manohar.

Limbale, S. (2004). Towards an Aesthetics of Dalit Literature; Histories, Controversies and Considerations. Orient Longman
Marx, K. (1873). Capital: A critical analysis of capitalist production. Humboldt.

Massey, J. (1997). Down trodden: the struggles of India's Dalits for identity, solidarity and liberation. Wcc Publications.

Pampirikunnu, Pratheepan. (2007). Dalit Study; Identity, Culture, Liberation. State Institute of Language.

Pawar, U. (2009). The Weave of My Life. Columbia University Press.

Thorat, S., \& Madheswaran, S. (2018). Graded caste inequality and poverty: evidence on role of economic discrimination. Journal of Social Inclusion Studies, 4(1), 3-29. 